\title{
Słowo wstępne
}

\section{Drogi Czytelniku!}

Przypada mi w udziale zaszczyt złożenia serdecznych podziękowań członkom Rady Biznesu Wydziału Ekonomiczno-Socjologicznego Uniwersytetu Łódzkiego, z jej przewodniczącym Panem Arkadiuszem Majsterkiem na czele, członkom Kolegium Dziekańskiego w kadencji 2008-2012, w szczególności zaś Pani Dziekan Profesor Bożenie Mikołajczyk - spiritus movens całego przedsięwzięcia, sekretarzowi Rady Doktor Agnieszce Kurczewskiej, zajmującej się z wielkim oddaniem organizacją funkcjonowania Rady oraz wspomagającej ją Doktor Iwie Kuchciak.

Niniejsza publikacja dokumentuje zaledwie fragment efektów współpracy koleżanek i kolegów z naszego Wydziału oraz Kolegium Dziekańskiego z Radą Biznesu, współpracy zmierzającej do udoskonalenia procesu dydaktycznego na Wydziale. Zbliżenie wykształcenia oferowanego naszym studentom do potrzeb praktyki gospodarczej przyjmowało różne formy - od doskonalenia we współpracy z członkami Rady Biznesu programów nauczania, przez organizowanie cyklu wykładów przybliżających studentom naszego Wydziału problemy funkcjonowania firm, po fundowanie przez członków Rady nagród dla wyróżniających się absolwentów. Do ciekawszych, choć raczej nietypowych owoców współpracy należy wprowadzenie nauki gry w golfa jako formy realizacji zajęć wychowania fizycznego dla studentów kierunków Ekobiznes oraz Finanse i rachunkowość, umiejętności jak sądzimy przydatnej w przyszłej biznesowej działalności naszych absolwentów. $Z$ wdzięcznością podkreślam, że nie udałoby się tego dokonać bez inicjatywy i wsparcia Pana Arkadiusza Majsterka.

Mam nadzieję, że Czytelnik znajdzie lekturę niniejszej pracy interesującą i użyteczną. 